\title{
KOGNITIIVINEN JÄRJESTELMÄ JA SEN YHTEYDET KASVATUKSEEN ISRAEL SCHEFFLERIN FILOSOFIASSA
}

\begin{abstract}
Lukiessani Israel Schefflerin tekstejä huomasin meitä molempia kiinnostavan ihmisen kognitiivinen järjestelmä ja kasvatus. Israel Scheffler on koulutusfilosofian tutkimuskeskuksen johtaja Harvardin yliopistossa. Hänen uransa alkoi Harvardissa jo vuonna 1952. Scheffleriä pidetään kasvatusfilosofina, joka on ollut pitkän uransa aikana kiinnostunut monista asioista, esimerkiksi kielifilosofiasta, tieteenfilosofiasta ja kasvatuksen kysymyksistä. Schefflerin ajattelua on Suomessa tutkittu varsin vähän, vaikka häntä pidetään englanninkielisellä alueella hyvin merkittävänä kasvatusfilosofiana.
\end{abstract}

\section{TIMO TOLSKA}

$\mathrm{T}$ arkastelen artikkelissa kognitiivisen järjestelmän näkökulmasta Schefflerin tekstien kasvatuksellista kieltä. Kysymykseni Schefflerille kuuluu, millainen on hänen käsityksensä kognitiivisesta järjestelmästä. Kyse on eräänlaisesta rekonstruktiosta eli pyrkimyksestä kasata Schefflerin eri aikoina julkaistuista teksteistä koottua esitystä kognitiivisesta järjestelmästä. Tämän lisäksi pohdin, millaisia kytkentöjä Scheffler rakentaa kognitiokäsityksensä kautta kasvatuksen suuntaan. Pääasiallisina lähteinä käytän Schefflerin omia erityisesti kognitiota käsitteleviä tekstejä, jotka sijoittuvat ajanjaksolle 1960-1986. Selittävänä teoksena käytän etupäässä kirjaa Reason and Education: Essays in Honor of Israel Scheffler (1997).

\section{KOGNITIIVINEN JÄRJESTELMÄ}

Sen ymmärtäminen, miten ihminen ajattelee, on pitkään ollut koulutustutkimuksen keskeinen osaalue. Käsityksemme kognitiivisen järjestelmän luonteesta nähdään ohjaavan pedagogisia käytäntöjämme. Tsai ja Huang $(2002,163)$ sanovat, että kognitiivisen järjestelmän tutkiminen on eri- tyisen tärkeää oppilaiden oppimisen tutkimisen kannalta. Kasvatus- ja kognitiotiede ovat pitkään pyrkineet määrittelemään kognitiivista järjestelmää (Tsai \& Huang 2001, 21). Esimerkiksi koulutustutkimuksessa on useiden vuosikymmenien ajan pyritty ymmärtämään opiskelijoiden käyttämiä kognitiivisia järjestelmiä (ks. esim. Preice 1976; West \& Pines 1985; Bahar, Johnstone \& Sutteliffe 1999). Kognitiivista jär-

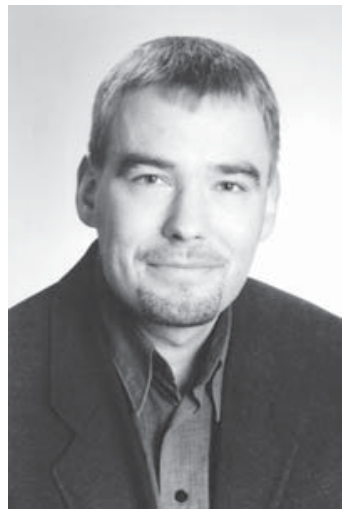

Timo Tolska jestelmää on tutkittu paljon myös monissa psykologian koulukunnissa.

Mitä termillä kognitiivinen järjestelmä tarkoitetaan? Shavelson (1974) mielestä kognitiivinen järjestelmä on hypoteettinen käsite, joka representoi käsitteiden välisiä suhteita oppijan pitkäkestoisessa muistissa. Tsai (2001) puolestaan sanoo, että kognitiivinen järjestelmä sisältää opiskelijan olemassa olevat kokemukset ja tiedot, jotka puolestaan ohjaavat heidän tulevien kokemusten jäsentämistä. Kognitiivisen järjestelmän sa- 
notaan myös olevan yksi ihmisen tiedonkäsittelyjärjestelmän kolmesta osasta. Muut osat ovat havaintojärjestelmä ja suorite- eli motorinen järjestelmä. Havaintojärjestelmän avulla ihminen vastaanottaa ympäristöstä tietoa, kognitiivinen järjestelmä hoitaa tiedon taltioinnin ja prosessoinnin ja motorinen järjestelmä vastaa toteutuksesta. Ihmisen ikääntymisen uskotaan aiheuttavan muutoksia pääasiassa kognitiiviseen järjestelmään, johon kuuluvat mm. eri muistijärjestelmät: sensoriset muistit eli aistimuistit, työmuisti ja pitkäkestoinen muisti. Kognitiivisen järjestelmän esitetään usein myös ohjaavan suoraan ihmisen toimintaa. Se sisältää mm. opitun taitotiedon, odotukset ja sisäiset mallit. Sisäisistä malleista käytetään usein nimitystä skeema. Erityisesti kognitiiviseen psykologiaan kuuluu uskomus, että sosiaalista maailmaa koskeva tietomme on varastoitunut mieleemme skeemoiksi (Helkama, Myllyniemi \& Liebkind 2001, 118). Kognitiivista psykologiaa kasvualustanaan käyttävissä oppimisnäkemyksissä lähdetään monesti siitä, että pitkäkestoisen muistin muistijäljet, kognitiiviset kartastot ohjaavat sitä, mihin tarkkaavaisuutemme kohdistuu ja miten prosessoimme uutta informaatiota. Näistä säilömuistiin talletetuista tietorakenteista on jo 1930-luvulta asti käytetty nimitystä skeema. Skeemat muodostavat hierarkisia, päällekkäisiä ja toistensa läpäiseviä verkostoja. Skeemat eivät koskaan ole valmiita tai suljettuja vaan muuttuvat jatkuvasti uusien kokemusten vaikutuksesta: ideat liittyvät toisiinsa ja käsitteet muuttuvat ja laajenevat. Tämän vuoksi skeemat ovat yksilöllisesti erilaisia. Skeemojen voidaan ajatella olevan kaikki, mitä ihminen tietää sisältäen hänen tuntemuksensa. Yleisellä tasolla termit skeema ja kognitiivinen järjestelmä pitävät sisällään varsin samanlaista argumentaatiota.

Millä muilla käsitteillä skeema lisäksi kognitiivisesta järjestelmästä puhutaan? Siitä käytetään myös termiä strukturaalinen tieto (structural knowledge) (ks. esim. Jonassen, Beissner \& Yacci 1993; Diekhoff \& Diekhoff 1982). Joskus siitä puhutaan myös lyhyesti termillä kognitio. Historiallista taustaa termille kognitiivinen järjestelmä voidaan hakea esimerkiksi 1950- ja 60-luvun taitteessa tapahtuneesta kognitiivisesta vallankumouksesta. Tällöin psykologian valtavirrassa aikaisempi behavioristinen käsitys sai antaa tilaa kognitiivisille näkemyksille. Kognitiivisen tradition sisällä esimerkiksi amerikkalaisen kasvatuspsykologin David Ausubelin kognitiivisen oppimisteo- rian avainkäsite on juuri oppijan kognitiivinen järjestelmä. Jo kauan ennen kuin myöhemmät kognitiivisen psykologian edustajat puhuivat skeemoista tärkeinä mieleen painamiseen ja muistamiseen vaikuttavina tekijöinä käytti Ausubel termiä kognitiivinen struktuuri, järjestelmä, samassa merkityksessä. Hänelle kognitiivinen struktuuri eli oppijan tiedot, käsitykset, odotukset ja muut informaation prosessointiin yhteydessä olevat tekijät oli oppimisen ja opetuksen kannalta kasvatuksen ja koulutuksen psykologian ydinkohta. ${ }^{1}$ Ausubelin käsityksen mukaan uuden oppiminen on uusien opittavien asioiden assimiloimista aikaisempaa kognitiiviseen järjestelmään. Tämän assimiloinnin kautta uudet asiat saavat merkityksen aikaisemmin opitun varassa. Samalla kuitenkin myös jo aikaisemmin opittu, nykyinen kognitiivinen järjestelmä akkomodoituu, kun siihen liitetään uusia sisältöjä. ${ }^{2}$

Kognitiivisen järjestelmän yhteydessä puhutaan usein myös emootiojärjestelmästä. Eri psykologian suuntauksissa emootiojärjestelmä tulkitaan kognitiiviselle järjestelmälle joko alisteisesta, rinnakkaisesta tai sen kanssa päällekkäisenä. Yhteistä eri tulkinnoille kuitenkin on, että niissä kaikissa nähdään sekä kognitiivisella että emootiojärjestelmällä olevan merkitystä ihmisen käyttäytymisen määräytymisessä. Kun ihmisen toimintaa on pyritty ymmärtämään, keskustelua on esimerkiksi käyty siitä, vaikuttaako ihmisen toimintaa enemmän kognitiivinen vai emootiojärjestelmä. Toisin sanoen on tutkittu, kumpi järjestelmä ohjaa ihmisen sisäisten mallien muodostumista enemmän jossakin tilanteessa.

\section{SCHEFFLERIN KÄSITYS KOGNITIIVISESTA JÄRJESTELMÄSTÄ}

Scheffler näkemystä ihmisen kognitiivisesta järjestelmästä on mahdollista lukea esiin ensinnäkin hänen pohdinnoistaan pontentiaalisuudesta (potentiality), erityisesti realisoituneesta potentiaalisuudesta. Yleinen ajatus, jonka ympärille olen tulkintaani seuraavassa rakentanut on, että ihmisillä on erilaisia pontentiaalisuuksia ja tätä kautta erilainen kognitiivinen järjestelmä. Potentiaalisuudella Scheffler viittaa ihmisen kehittymisen, muutoksen ja oppimisen mahdollisuuteen, jotka ovat ominaisia kognitiiviselle järjestelmälle. Meille on välittynyt mm. Aristoteleen metafysiikan kautta käsitys, jonka mukaan yhtäältä ih- 
misen luontaiset ominaisuudet ja toisaalta päämäärät, joita kohti ihminen elämässään etenee, määrittävät hänen olemuksensa. Tämä ajatus on Scheffleristä kuitenkin ongelmallinen. Se ei anna tarpeeksi tilaa muutoksen, oppimisen ajatukselle. Lisäksi Scheffler kysyy, onko ylipäätään mielekästä pyrkiä selittämään joidenkin oletettujen ihmisten luontaisten piirteiden avulla hänen todellista kehittymistä (Scheffler 1991, 24). Schefflerin oma vastaus on epäilevä. Hän painottaa ihmisen kehitykselle luonteenomaista suurta joustavuutta ja muutoksellisuutta sekä ympäristön voimakasta vaikutusta.

Potentiaalisuuksissa ei ole kysy ihmisen luonnollisista olemuksista (essence). On harhaanjohtavaa sanoa, että ainoastaan tietyillä ihmisillä olisi esimerkiksi potentiaalisuus pianon soittoon, erityinen pianon soiton olemus (essence of piano playing). Schefflerin mielestä osuvampi ilmaus on, että potentiaalinen pianisti saattaa hankkia kyvyn (acquire the ability) soittaa pianoa tulevaisuudessa. Ne taas, jotka eivät ole potentiaalisia pianisteja, eivät todennäköisesti hanki tätä taitoa. (Scheffler 1991, 25; 1985, 45-46.) Potentiaalisuus voidaan näin ymmärtää ihmisen kapasiteettina tiettyjen piirteiden hankkimiseen (capacity for acquisition) (Scheffler 1991, 26, 29; 1985, 46-48, 61). Puheella oppilaan potentiaalisuudesta olla esimerkiksi urheilija, matemaatikko tai vaikkapa kirvesmies viitataan hänen kykyynsä (capability) oppia näihin liittyviä taitoja. Heti perään Scheffler kuitenkin huomauttaa, että potentiaalisesta pianistista ei välttämättä tule tulevaisuudessa koskaan todellista pianon soittajaa, hänen potentiaalisuutensa ei ehkä pääse milloinkaan realisoitumaan. Potentiaalisuuksista itsestään ei toisin sanoen voi koskaan ennustaa niiden aktualisoitumista tulevaisuudessa. Tämä Schefflerin ajatus käy ymmärrettäväksi hänen kulttuurin vaikutuksia korostavan kehityskäsityksen kautta. Sanottaessa, että ihmisellä on potentiaalisuus johonkin, se ei tarkoita, että hän kykenee tekemään jotain asiaa. Kyse on pikemminkin siitä, että ihmisellä voi olla kapasiteetti tulla (capacity to become) joksikin. Hänellä ei ole nyt esimerkiksi taitoa soittaa pianoa, mutta hänellä on kapasiteetti hankkia tämä taito. Hän kykenee oppimaan kuinka soitetaan. Potentiaalisuus viittaa jonkin taidon puuttumiseen (manifest lack) juuri nyt, mutta samalla mahdollisuuteen hankkia tämä kyky tulevaisuudessa.

Kulttuurilla on keskeinen asema ihmisen tai- don oppimisen, kognitiivisen järjestelmän, kehityksen kannalta (Scheffler (1991, 26, 29). Eri kulttuurit poikkeavat toisistaan siinä, että ne avaavat oppimiselle erilaisia mahdollisuuksia. Yhden kulttuurin mahdollistaessa oppimisen toinen kulttuuri sulkee sen pois. Scheffler (1991, 108; 1985, 105) käyttää tästä nimitystä potentiaalisuuden suhteellisuus (relativity of potential). Eri kulttuurit muovaavat sille tyypillisten oppimiskäytäntöjen kautta kognitiivista järjestelmää kulloinkin vallitseviin olosuhteisiin sopivaksi. Schefflerin nähdessä kognitiivisen järjestelmämme hyvin herkäksi ympäristön, kulttuurin vaikutuksille hän korostaa moraalista vastuutamme kehittää tiettyjä potentiaalisuuksia ja estää toisia kehittymästä (Scheffler 1991, 22, 107-108; 1985, 104). Väittämällä, että potentiaalisuudet ovat kullekin yksilölle luontaisia, yritämme vain väistää tätä moraalista vastuuta, sanoo Scheffler $(1991,24)$. Jokainen kasvatuksessa tehtävä muutos avaa aina uusia oppimismahdollisuuksia ja sulkee pois toisia (Scheffler 1991, 20, 22, 47). Scheffler sanoo, että kouluissa ja yhteiskunnassa yleisemmin olisi jatkuvasti keskusteltava, minkälaisia potentiaalisuuksia ihmisissä pyritään realisoimaan. Kyse on aksiologisista, epistemologisista ja ontologisista valinnoista, joista tulisi aina yhteisesti ja julkisesti päättää.

I hmisellä on useita potentiaalisuuksia. Kyky oppia on yksi niistä (Scheffler 1985, 121). Oppiminen perustuu potentiaalisuuksiin, joita koulutuksen avulla pyritään realisoimaan (realization). Potentiaalisuuksien realisoituminen muuttaa ihmistä (becomes a different person) (Scheffler 1991, 19). Koulutus (study, training) on mahdollista nähdä tätä kautta potentiaalisuuksien realisoimiseksi. Keskeiseksi kysymykseksi nousee, minkälaisten kurssien ja harjoitusten kautta voidaan parhaiten auttaa opiskelijoita realisoimaan heidän potentiaalisuuksiaan? Vaikka ihmisellä olisi jokin potentiaalisuus, se ei nimittäin ilman harjoitusta realisoidu (Scheffler 1991, 18, 19). Potentiaalisuuksien realisoitumisen kannalta tärkeää on saada ulkoiset olosuhteet mahdollisimman edullisiksi (Scheffler 1991, 110).

Scheffler käsityksen mukaan on ilmeistä, että kaikilla ei ole samoja potentiaalisuuksia. Koulutuksen avulla voimme kuitenkin auttaa opiskelijoita saavuttamaan potentiaalisuuksia, jota heillä ei tähän asti ole ollut. Toisin sanoen opiskelija, jolta tällä hetkellä puuttuu jokin potentiaalisuus, 
voi koulutuksen avulla saavuttaa sen tulevaisuudessa (Scheffler 1991, 18). Scheffler kirjoittaa: "Vaikka potentiaalisuuden nykyinen puuttuminen estää sen tämän hetkisen realisoimisen, se ei estä sen realisoimista myöhemmin, kun tämä kyseinen potentiaalisuus on hankittu" (Scheffler 1991, 18). Schefflerin näyttää toisin sanoen ajattelevan, että potentiaalisuuksia voidaan myös oppia. Tietty kognitiivinen järjestelmä, joka rakenteensa eli potentiaalisuuksiensa kautta kykenee tiettyyn toimintaan, voi opetuksen kautta saavuttaa uusia toimintamuotoja. Schefflerin ajattelussa painottuu mielestäni erityisesti potentiaalisuuksien realisoitumisen sosiaalinen ulottuvuus. Scheffler $(1991,109,113$. ) kirjoittaa, että jos jotain potentiaalisuutta ei saada realisoitua, kyse ei ole koskaan yksin lapsesta, vaan aina lapsen ja ympäristön (child-and-context) vuorovaikutuksesta. Interaktionismi (interactionism) korvaa Schefflerillä essentialismin (essentialism). Kognitiivinen järjestelmämme rakentuu aina suhteessa toisiin. Ihmisen potentiaalisuuksien varasto, ihmisen kognitiivinen rakenne, vaihtelee ajan ja ympäristön mukaan (Scheffler 1991, 19, 20). Kyse ei siis ole perityistä ominaisuuksista. Ihmisen nykyiset potentiaalisudet eivät määrää, mitä potentiaalisuuksia hänellä voi tulevaisuudessa olla, menneisyys ei tosin sanoen determinoi tulevaisuutta. Tulevat potentiaalisuudet määräytyvät pitkälti opiskelijan intentioista, (individuaalisista ja sosiaalisista) sekä saatavissa olevista resursseista (Scheffler 1991, 19).

Eri potentiaalisuudet muodostavat toisiinsa kytkeytyvän verkoston, jossa jokainen potentiaalisuuden realisoituminen vaikuttaa myös muihin potentiaalisuuksiin (Scheffler 1991, 19, 113; $1985,11)$. Potentiaalisuudet ovat usein myös toistensa kanssa ristiriidassa. Lisäksi monesti uudet potentiaalisuudet ovat peräisin vanhojen potentiaalisuuksien realisoitumisesta. Esimerkiksi matemaattisten potentiaalisuuksien realisoituminen tuottaa usein uusia matematiikkaan liittyviä potentiaalisuuksia. Syntyneitä uusia potentiaalisuuksia voidaan taas pyrkiä koulutuksella realisoimaan. Scheffler $(1991,19)$ ei myöskään halua kieltää transfer-vaikutusta muille potentiaalisuuksien alueille. Hän nimittäin sanoo, että potentiaalisuuksien parantuminen yhdellä alueella voi parantaa myös toisia potentiaalisuuksia. Näin ollen monet esimerkiksi matematiikkaan liittyvät taidot saatavat olla hyödyllisiä myös matematiikan ulkopuolella (Scheffler 1991, 73).
Schefflerin ajattelussa painottuu siis näkemys, että ihmisellä ei ole kiinteitä potentiaalisuuksia, tulkintani kautta kiinteää kognitiivista järjestelmää. Koulutuksen tehtäväksi tulee edistää ja parantaa oppilaan potentiaalisuuksien varantoa, kognitiivista järjestelmää (vrt. Scheffler 1991, 20 $21 ; 1985,11,42,45,91,110)$. Potentiaalisuudet eivät itsestään realisoidu oppilaalla hänen kehittyessään. Koulutuksen kautta tulisi pyrkiä realisoimaan oppilaiden olemassa olevia potentiaalisuuksia oikeina kriittisinä kausina. Jos kriittinen kausi ohitetaan, jokin potentiaalisuus saatetaan kokonaan menettää (Scheffler 1985, 13, 72-74). Sen lisäksi koulutuksen avulla tulisi pyrkiä myös löytämään opiskelijoiden vielä piilossa olevia potentiaalisuuksia sekä estää jo saavutettuja potentiaalisuuksia katoamasta.

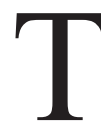
arkastelen seuraavaksi edellistä Scheffler tulkintaani potentiaalisuuksista kognitiivisena järjestelmänä laajemmasta näkökulmasta. Ihmisillä on realisoituneena erilaisia potentiaalisuuksia, heidän kognitiivinen järjestelmänsä vaihtelee. Kulttuurilla ja koulutuksella sen osana on merkittävä asema potentiaalisuuksien realisoimisessa ihmisen pyrkiessä sopeutumaan kulloinkin vallitseviin olosuhteisiin. Koska yhden potentiaalisuuden realisoituminen (sen lisäksi, että se avaa mahdollisuuksia uusille potentiaalisuuksille) sulkee myös pois monia muita, ihminen ei voi koskaan olla kaikkea, mitä hän voisi olla. Schefflerin potentiaalisuustarkastelussa tulee mielestäni esiin käsitys kulttuurin vahvasta merkityksestä kognitiivisen järjestelmän, yleisemmin ihmisen kehittymisessä. Schefflerin painotukset tulevat ajoittain varsin lähelle kulttuuripsykologien ajatuksia. Esimerkiksi Jerome Bruner kirjoittaa, että inhimillistä mieltä ja elämää muovaa biologian asemasta kulttuuri (Bruner 1990, 34). Jopa yksilölliset erot mielen ominaisuuksissa ja käytössä ovat erilaisten kulttuuriympäristöjen seurausta, vaikka ympäristö ei yksin määrääkään mentaalista toimintaa (Bruner 1996, 4). ${ }^{3}$ Kulttuuripsykologian kautta hahmottuu ajatus, jonka mukaan on virheellistä nähdä ihmisen potentiaalisuudet synnynnäisinä ja pysyvinä rakenteina, jotka kehittyvät itsekseen. Kulttuuripsykologia ei pyri kieltämään soomaa, biologiaa, vaan näyttää, kuinka ihmisten mielet ja tavat elää ovat kulttuurin ja historian heijastumia (Bruner 1990, 138). Ihmisen mielen evolutionaarinen kehittyminen kytkeytyy kulttuuriin. Kognitiivinen järjestelmä 
kehittyy pitkälti "ulkoa sisään", kulttuurin symbolisten ja praktisten välineiden luodessa erilaisia kehitysmahdollisuuksia kognitiolle. Kognitiivisen järjestelmän rakenne riippuu paljon siitä, kuinka kulttuuri onnistuu tarjoamaan intellektuaalisia työkaluja ihmisen käyttöön (Bruner 1971, 7.) Kognition rakenne on riippuvainen kulttuuristen resurssien käytöstä (Bruner 1996, 4). Ihmisten luontaiset piirteet eivät ole toimintamme syitä, vaan pikemminkin toimintaamme rajoittavia tekijöitä tai sen edellytyksiä.

Schefflerin potentiaalisuuksia koskeva transfer-argumentti taas ankkuroituu osaksi pitkää perinnettä. Vuosisatojen ajan esimerkiksi latinaa opetettiin kouluissa, koska uskottiin, että se edesauttaa järjestelmällistä ajattelua. Theodoro Roszak $(1986,53)$ toteaa, että kuten entisaikojen latinistit, atk-alan asiantuntijat ajattelevat nykyisin matematiikasta ja logiikasta samalla tavoin. Roszak suhtautuu kriittisesti transfer-argumenttiin todetessaan, että luultavasti esimerkiksi symbolinen logiikka ei opeta mitään muuta kun symbolista logiikkaa. Saman päättelyn voi laajentaa koskemaan kaikkia muitakin aineita. Roszakin kritiikki tuntuu varsin uskottavalta, mutta toisaalta houkuttelisi seurata myös Scheffleriä ja väittää, että jonkun asian sisällön hallinta auttaa oppimaan myös muita asioita, jotka sisällöllisesti poikkeavat siitä. Todeta, että monet opitut rakenteet toistuvat usein myös toisissa opiskeltavissa asioissa, jolloin ne ovat mahdollista oppia sieltä nopeammin. Kumulatiivinen opiskelu lisäisi näin kykyämme ymmärtää yleispäteviä lainalaisuuksia ja eri sisällöissä toistuvia rakenteita.

\section{KOGNITIIVINEN JÄRJESTELMÄ KIELELLISENÄ SYMBOLIJÄRJESTELMÄNÄ}

Schefflerin ajatuksia kognitiivisesta järjestelmästä on mahdollista paljastaa myös tutkimalla hänen käsityksiään kielen ja kognition välisestä suhteesta. Kognitiolle on tyypillistä, että sillä muovataan "raaka materiaalia" eli kokemuksia, jotka puolestaan muovaavat kognitiota. Kyse ei ole prosessista, jossa ihminen vain "pakottaisi" kokemuksia omiin abstrakteihin ajattelurakenteisiinsa (Scheffler 1991, 35; 1985, 78). Koska kokemukset muovaavat merkittävällä tavalla kognitiotamme, ihminen hahmottuu Schefflerin filosofiassa kulttuurin tuottamaksi, mutta myös aktiiviseksi kulttuurin tuottajaksi (vrt. Wagner 1997, 251). Ihmi- nen on merkittävällä tavalla riippuvainen muiden ihmisten tekemistä valinnoista. Scheffler (1991, 23) arvelee, että kulttuurilla ja koulutuksella on perimää vahvempi asema yksilön muokkaajana. Kulttuuri muovaa yksilöä erityisesti symbolisten järjestelmiensä kautta. Ihmiselle on lajina ominaista erityinen symbolien prosessointikyky (Scheffler 1991, 73). Ihminen on symbolinen eläin (symbolic animal), joka symboloi (symbolize) ympäristöään. Hänen ajattelunsa on diskurssisidonnaista. (vrt. Scheffler 1986, 84; 1967, 42; 1991, 61.) Kielen symbolisysteemien avulla luotavat representaatiot ovat ihmisen keskeisin väline kuvata maailmaa, ilmaista uskomuksia ja päätöksiä, lausua mieltymyksiä ja velvollisuuksia, systematisoida filosofisia vakaumuksia ja tieteellistä informaatiota (Scheffler 1993, 128; 1985, 17). Ihmisen toiminnan ymmärtäminen edellyttää hänen käyttämiensä symbolisysteemien (symbolic systems) tuntemista (Scheffler 1991, 106; 1985, 102).

Tietomme maailman objekteista on aina kielellisten esioletustemme, kategorisointiemme, käsitteellisten uskomusjärjestelmiemme eli oppimamme kognitiivisen järjestelmän suodattamaa (Scheffler 1974, 128). Meillä ei ole mahdollisuutta päästä oman kognitiivisen järjestelmämme ulkopuolelle. Scheffler ajattelee pitkälti Immanuel Kantin tavoin, että ihminen elää itse representoimassaan maailmassa eikä hänellä ole mahdollisuutta tarkastella "todellisuutta sellaisenaan". Tämän vuoksi emme saa varmaa tietoa sen enempää aistihavaintojemme kuin intuitiivisen tietämyksemmekään avulla. Joudumme siis hyväksymään tiedon suhteen aina tietyn epävarmuuden. Tämä ei kuitenkaan ole Schefflerin mielestä riittävä peruste hylätä ontologista realismia eli oletusta meistä ja tietämisestämme riippumattomasta todellisuudesta eikä väitettä mahdollisuudestamme saavuttaa todellisuudesta sellaista tietoa, jonka paikkansapitävyyttä voimme arvioida (ks. esimerkiksi Scheffler 1967). Scheffler uskoo, että meillä on mahdollisuus saavuttaa jonkinlaista, joskin epävarmaa, tietoa itsemme ulkopuolisesta ja kognitiivisesta järjestelmästämme riippumattomasta todellisuudesta.

$\mathrm{R}$ elativismin vastustajana Scheffler ei suhtaudu suopeasti ajatukseen, että kaikki kognitiivisella järjestelmällämme tuotettu tieto olisi yhtä pätevää. Miten sitten voimme asettaa eri tulkintoja paremmuusjärjestykseen? Käytännön kokemuksista, toiminnasta, saamiemme 
kokemusten kautta huomaamme, että kaikki kognitiivisella järjestelmällä luodut ideat eivät ole yhtä hyviä (Scheffler 1965, 4, 39, 46-47). Ihmisen kehitykseen liittyy siis olennaisesti se, että pyrimme oppimaan systemaattisella tavalla käytännön kokemuksista. Ideoiden toimivuutta testataan toiminnassa (in action), käytännössä (trying an idea in practice). Voidaankin sanoa, että symbolijärjestelmällä luotavien ideoiden totuuden määrittää näin ollen viime kädessä tästä symbolijärjestelmästä riippumaton todellisuus. Todellisuus ei ole vain oman kognitiivisen järjestelmämme luomus (Scheffler 1986, 277). Symbolijärjestelmämme ei luo maailmaa. Maailmaa ei goodmanilaisittain tehdä (worldmaking) symbolijärjestelmien avulla (Scheffler 1986, 274-278). Kyse on pikemminkin siitä, että me teemme eri symbolijärjestelmien avulla todellisuudesta eri versioita ja asiat, jotka ovat meidän, muiden ja ei kenenkään tekemiä, tekevät ne oikeiksi (Scheffler 1986, 85, vrt. 1997, 206). Lisäksi Scheffler fallibilistina katsoo, että tällä hetkellä tietona pitämämme asiat ovat tilapäisiä hypoteeseja, jotka jäävät aina tulevaisuuden kokemusten testattaviksi (ks. Scheffler 1965, 47).

Schefflerin kannattamassa pragmatismissa uskotaan ajattelun representatiiviseen luonteeseen (representative character of thinking). Kognitiivisen järjestelmänsä avulla ihminen tulkitsee objekteja niiden symbolisten representaatioiden, kohteita edustamaan asetettujen merkkien kautta (Scheffler 1991, 159). Kognitiivinen järjestelmämme hahmottuu toisistaan riippuvaisten merkkiprosessien verkostoksi, jonka avulla ei kuitenkaan koskaan saavuteta totuutta, varmuutta. Merkkejä tai symboleita ei pidetä todellisuuden kuvina (picture) tai mielikuvina (images). Ne tulkitaan pikemminkin eräänlaisiksi apuvälineiksi. Käsitteet eivät ole kohteen tyhjentäviä ja täydellisiä representaatioita. Ne saattavat kyllä näyttäytyä kohteen keskeisinä piirteinä, mutta vain meidän omasta näkökulmastamme (for our purpose).

Schefflerin sanoo, että on olemassa rinnakkaisia ja osin yhteismitattomia symbolijärjestelmiä. Ihminen voi toisin sanoen siirtää kokemuksiaan, kuvata todellisuutta useilla symbolijärjestelmillä (ks. esim. Scheffler 1986, 276; 1991, 160; 1997, 206). Nämä keskenään rinnakkaiset ja yhteismitattomat symbolijärjestelmät palvelevat eri tavoin inhimillistä elämää (Scheffler 1997, 206).

Ajatus samanaikaisesti toisista ja keskenään ristiriitaisista symbolijärjestelmistä ei sen sijaan
Scheffelerin ajatteluun sovi (Holma 2000, 6). Samoja asioita voidaan ilmaista niin tieteen kuin taiteenkin symbolijärjestelmillä. ${ }^{4}$ Lisäksi Scheffler huomauttaa, että tieteellä ei hänen mielestään ole maailman kuvauksessa etuoikeutettua asemaa verrattuna taiteeseen. Schefflerin edellisten ideoiden pohjalta voidaan ajatella, että opiskelijoilla on erilaisia kognitiivisia järjestelmiä. Eri opiskelijat käyttävät näin ollen erilaisia symbolijärjestelmiä opetuksessa tarjottujen oppimiskokemustensa jäsentämiseen. Koulun tehtäväksi tulee kehittää ja pitää yllä symbolisysteemejä, joita opiskelijat käyttävät opiskelussaan (vrt. Scheffler 1991, 160, vrt. 1974, 60). Koulutuksen avulla emme ainoastaan siirrä sitä, mitä tiedämme, vaan siirrämme myös tietämisen tapaamme (Scheffler 1965, 2). Tietämisen tapamme määrää juuri käyttämämme symbolijärjestelmä.

$\mathrm{M}$ istä laajemmasta ajatteluperinteestä Schefflerin edelliset ajatukset kognitiivisesta järjestelmästä kielellisenä symbolisysteeminä antavat vihjeitä? Sen lisäksi, että edellisessä keskustelussa tuli jälleen esiin Schefflerin kulttuuripsykologiaa myötäileviä ajatuksia, näkyy siinä myös pragmatismin vaikutus. Esimerkiksi yhdysvaltalaisen Charles Anders Peircen ajattelusta vaikutteita saaneeseen pragmatismiin kuuluu ajatus, että ajattelu perustuu merkkeihin. Tieto ulkoisesta ja sisäisestä maailmasta pohjautuu hypoteeseihin ja niiden testaamiseen havaintojen avulla. Tieto nähdään aina jotenkin epävarmana (fallibilismi). Ihmisten uskomusten ajatellaan kehittyvän kiinteässä yhteydessä toimintaan. Käsitteiden, symbolisten merkkien, merkitys sisältyy niiden referenttien käytännöllisiin seurauksiin. Tosin sanoen selvittääksemme jonkin intellektuaalisen käsitteen merkityksen tutkimme, mitä käytännöllisiä seurauksia voisi seurata tämän käsitteen totuudesta. Teoriat kielellisinä symbolisina järjestelminä voidaan nähdä instrumenteiksi kokemusten järjestämiseksi ja niiden totuus liittyy niiden toimivuuteen ja hyödyllisyyteen.

Edelliseen käsitykseen viitataan usein termeillä instrumentalismi tai eksperimentalismi. Tässä pragmatismin lajissa, jota on kehitellyt esimerkiksi Dewey, teoriat ovat siis luonteeltaan välineitä kokemusten jäsentämiseksi ja ongelmien ratkaisemiseksi. Dewey ajattelee myös Schefflerin tavoin, että uskomukset ovat välineitä ihmisen sopeutumisessa ympäristöönsä. ${ }^{5}$ 


\section{RATIONAALISUUS JA EMOOTIOT KOGNITIIVISESSA \\ JÄRJESTELMÄSSÄ}

Scheffler $(1991 ; 1974,62,78 ; 1965,7)$ puhuu kognitiivisen järjestelmän yhteydessä myös rationaalisuudesta (rationality). Rationaalisuuden periaatteet eivät ole kognitiivisen järjestelmämme luonnollisia rakenteita ja näin kaikille ihmisille yhteisiä. Konkreettiset säännöt ja tekniikat, jotka määräävät päättelyä ja menettelytapoja, eivät voi olla Schefflerin mielestä ihmisen mielen myötäsyntyisiä rakenteita (ks. Scheffler 1974, 78). Scheffler (1974, 78-79) kytkee rationaalisuuden tradition käsitteeseen. Rationaalisuudessa ei ole kyse pelkästään abstraktista ja yleisestä ideaalista, vaan se muodostuu monista kehittyvistä traditioista (Scheffler 1974, 79). Rationaalisuudella viitataan siihen, että kognitiiviset prosessit ovat sopusoinnussa niitä kontrolloivien rationaalisten ideaalien ja normien kanssa. Scheffler painottaa myös, että järki ei ole kuitenkaan koskaan vailla tunnetta. Rationaalisuus rakentuukin aina suhteessa emootioihin (Scheffler 1991, 5). ${ }^{6}$

Schefflerin mielestä kognitiiviseen järjestelmään kuuluvat myös emootiot. Mitä emootiolla tarkoitetaan? Emootion (emotion) uskotaan olevan aktuaalinen, intentionaalinen psykofyysinen tila, jonka temporaalinen kesto on muutamista sekunneista useaan minuuttiin. Sen osatekijöitä ovat yleensä itselle relevanttia muutosta koskeva havainto, uskomus ja arvio, fysiologisen aktivaatiotilan ja toimintavalmiuden muutos, tietty affektiivinen tuntemuksen laatu sekä kasvonilme. Emootioilla viitataan usein käyttäytymistä liikkeelle paneviin voimiin, psyykeen energiatalouteen. Ne ovat tunteenomaisia elämyksiä, esimerkiksi ilon, pelon ja surun kokemuksia. Emootioiden on sanottu olevan myös psyykkinen prosessi, jolla on tietty alku ja joka voi johtaa tiettyyn esimerkiksi elämykseen tai kasvonilmeeseen. Emootioiden sanotaan perustuvan ensinnäkin johonkin tilanteen arviointiin. Toiseksi emootioiden uskotaan pohjautuvan aivoprosesseihin, esimerkiksi tiettyjen hormonien eritykseen ja siitä seuraavaan fysiologiseen virittymiseen. Vuorovaikutuksessa motiivien kanssa emootioiden nähdään toimivan ihmisen toiminnan ohjaajina. Varsin yleinen käsitys on, että koemme elämykset aina sekä kognitiivisesti että elämyksellisesti. Eri tulkinnat vaihtelevat siinä, nähdäänkö tunteet kognitiolle alisteisina, jatkuvasti rinnakkain toimivina samanarvoisina järjestelminä vai katsotaanko, että koko käsitteellinen erottelu näiden kahden järjestelmän välillä on ongelmallinen. Tämä kolmas tulkinta lähtee ajatuksesta, että tunteet ja kognitio toimivat jatkuvasti toisiinsa kietoutuneina: todellisuus välittyy meille merkityksenannossamme jaettujen symbolijärjestelmien ja niihin liittyvien tunnelatausten kautta. Tilanteenmäärittely yhdistetään aina aivoissa tunnekokemuksiin.

Scheffler kytkee järjen ja tunteet kiinteästi toisiinsa (ks. Scheffler 1974, 78; 1991, 8, 3). Hänen mielestään emootioita ja kognitiota ei voida eristää toisistaan, koska kognitiivisessa toiminnassa on aina mukana emotionaalisia elementtejä. Toisin sanoen kognitiiviset ja emotionaaliset elementit kietoutuvat toisiinsa ajattelussa. Molempien avulla ihminen pyrkii sopeutumaan ympäristöönsä. Kognitiivisen järjestelmän avulla tehtävät kokemusten symboloinnit sisältävät aina tunnelatauksia, emootioita. Todellisuus välittyy meille semanttisten symbolien ja niihin liitettyjen tunnelatausten kautta, ei koskaan suoraan. Toisin sanoen kognitiivisen järjestelmän kielellisyys saa voimansa tunteista, sanat saavat voimansa emootioista. Scheffler $(1991,3)$ pitää harhaanjohtavana ajatusta, että kognitiiviset toiminnat vallitsisivat tieteessä ja emotionaaliset taiteessa. Emootiot auttavat tieteessä luomisprosessia samalla tavoin, kuin ne tekevät runoudessa ja taiteessa (Scheffler 1991, 9). Koulutuksen kannalta edelliset argumentit tarkoittavat, että kognition kehittämistä ei voida erottaa emootioiden kehittämisestä (education of the emotion) (vrt. Scheffler 1991, 15, Yob 1997, 55). Emootioilla on myös tärkeä tehtävä tieteellisen mielikuvituksen stimuloimisessa (Yob 1997, 47). Ilman mielikuvitusta ei voi olla tiedettä (Scheffler 1991, 8). Sen avulla voimme asettaa vanhoja "faktoja" uusiin yhteyksiin ja valottaa näin meille pimentoon jääneitä horisontteja todellisuuteen.

\section{LOPUKSI}

Artikkelissa on pyritty pitäytymään varsin tiukasti Schefflerin omissa teksteissä ja rakentamaan eri aikoina ja eri julkaisuissa esitettyjen argumenttien pohjalta synteesiä, yleistä esitystä hänen käsityksestään kognitiivisesta järjestelmästä ja sen yhteyksistä kasvatukseen.

Hahmotin aluksi kognitiivista järjestelmää käyttäen termiä potentiaalisuus. Kognitiivinen 
järjestelmä muodostui tämän tarkastelun kautta kunkin ihmisen kulloinkin realisoituneista potentiaalisuuksista. Merkittäväksi tekijäksi tässä potentiaalisuuksien realisoitumisessa nousi ihmistä ympätöivä kulttuuri. Kasvatuksella on tätä kautta keskeinen vaikutus kognitiivisen järjestelmän kehitykselle. Löysin tässä kohti Schefflerin ajattelussa yhtymäkohtia erityisesti kulttuuripsykologiseen traditioon.

Toiseksi pohdin Schefflerin ajatuksia kognitiivisesta järjestelmästä kielellisenä symbolisysteeminä. Schefflerin mielestä kognitiivinen järjestelmä on pitkälti kielellinen systeemi. Kohtaamme todellisuuden kognitiivisella järjestelmällä muodostamiemme symbolisten representaatioiden kautta. Kasvatuksen välityksellä tarjoamme kognitiiviselle järjestelmälle erilaisia symbolisysteemeitä kokemusten hahmottamiseksi. Eri symbolijärjestelmien paremmuus jonkin kokemuksen jäsentämisessä ratkaistaan niiden käytännöllisten seurausten perusteella. Tässä tarkastelussa toin esiin Schefflerin ajattelun yhtymäkohtia hänen kannattamaansa pragmatistiseen perinteeseen.

Kolmanneksi pohdin, miten rationaalisuus ja emootiot liittyvät kognitiiviseen järjestelmään. Scheffler näki niiden molempien muodostavan yhdessä kognitiivisen järjestelmän ytimen.

Minkälaisia jatkotutkimuksen aiheita keskusteluni Schefflerin kanssa herätti? Edellisten kolmen näkökulman lisäksi Schefflerin käsitystä kognitiivisesta järjestelmästä voisi tutkia pohtimalla kognitiivisen järjestelmän kehitystä Schefflerin kasvu- ja muovausmetaforien kautta. Lisäksi voisi miettiä kognitiivisen järjestelmän käyttämää metaforista ja kirjaimellista kieltä sekä kognitiivisessa järjestelmässä tapahtuvia muutoksia Schefflerin yllätyksen tunnetta koskevien argumenttien kautta.

\section{LÄHTEET}

Ausubel, D.P. (1968) Educational psychology: A Cognitive View. New York: Holt, Rinehart \& Winston.

Bruner, J.S. (1971) The Relevance of Education, London: George Allen \& Unwin Ltd.

Bruner, J.S. (1990) Acts of Meaning, Cambridge, Massachusetts: Harvard University Press.

Bruner, J.S. (1996) The Culture of Education, Cambridge, London: Harvard University Press.

Bahar, M., Johnstone, A.H. \& Sutteliffe, R.G.
(1999) Investigation of students' cognitive structure in elementary genetics through word association tests. Journal of Biological Education 33, 134-141.

Diekhoff, G.M. \& Diekhoff, K.B. (1982) Cognitive maps as a tool in communicating structural knowledge. Educational Technology 22, 28-30.

Helkama, K., Myllyniemi, R. \& Liebkind, K. (2001) Johdatus sosiaalipsykologiaan. Helsinki: Edita.

Holma, K. (2000) Rationaalisuus ja kasvatus Israel Schefflerin filosofiassa. Helsinki: Helsingin yliopisto.

Jonassen, D.H., Beissner, K. \& Yacci, M. (1993) Structural knowledge: Techniques for representing, conveying and acquiring structural knowledge. New Jersey, USA: Lawrence Erlbaum Associates, Inc.

Preece, P.F.W. (1976) Mapping cognitive structure: A comparison of methods. Journal of Educational Psychology 68, 1-8.

Scheffler, I. (1965) Conditons of Knowledge. An Introduction to Epistemology and Education. Chicago, Atlanta, Dallas, Palo Alto, Fair Lawn, N.J.: Scott, Foresman and Company.

Scheffler, I. (1967) Science and Subjectivity. Indianapolis, New York: Bobbs-Merrill.

Scheffler, I. (1974) Reason and Teaching. London. Routledge \& Kegan Paul.

Scheffler, I. (1985) Of Human Potential. An Essay in the Philosophy of Education. Boston, London, Melbourne and Henley: Routledge \& Kegan Paul.

Scheffler, I. (1986) Inquiries. Philosophical Studies of Language, Science and Learning. Indianapolis. Hacket Publishing Company.

Scheffler, I. (1991) In Praise of the Cognitive Emotions and Other Essays in the Philosophy of Education. New York, London: Routledge.

Scheffler, I. (1993) Responses. Synthese. 94 (1), 55-83.

Scheffler, I. (1997) Replies. Studies in Philosophy and Education 16 (1-2), 58-72.

Shavelson, R.J. (1974) Methods for examning representations of a subject-matter structure in a student's memory. Journal of Research 
in Science Teaching 11, 231-249.

Tsai, C. (2001) Probing students' cognitive structures in science: The use of a flow map method coupled with a meta-listening technique. Studies in Educational Evaluation 27, 257-268.

Tsai, C. \& Huang, C. (2001) Development of cognitive structures and information processing strategies of elementary school students learning about biological reproduction. Journal of Biological Education 36 (1).

Tsai, C. \& Huang, C. (2002) Exploring student's cognitive structures in learning science: a review of relevant methods. Journal of Biological Education 36 (4).

Wagner, P.W. (1997) Total Quality Management: A Plan for Optimizing Human Potential? Teoksessa Harvey Siegel (toim.) Reason and Education: Essays in Honor of Israel Scheffler. Dordrecht: Kluwer.

West, L.H.T. \& Pines, A.L. (1985) Cognitive structures and conceptual change. Orlando: Academic Press.

Yob, I.M. (1997) The Cognitive Emotions and Emotional Cognitions. Teoksessa Harvey Siegel (toim.) Reason and Education: Essays in Honor of Israel Scheffler. Dordrecht: Kluwer.

\section{VIITTEET}

1

Ks. Ausubel 1968.

2 Ajatus voidaan ilmaista myös niin, että kokemukset syöpyvät hermokytkennöiksi, jotka suodattavat uusia kokemuksia itseään vahvistavalla tavalla. Kognitiivinen järjestelmä muuttuu, kun kokemuksia mallintava hermoverkko muovautuu uusien kokemusten myötä.

3 Kulttuuripsykologiaan voi tutustua tarkemmin mm. seuraavien teosten kautta: Jerome Bruner Acts of Meaning (1990), Michael Cole The Cultural Context of Learning and Thinking. An Exploration in Experimental Antropology (1971), Richard Scweder Thinking Through Cultures: Expeditions in Cultural Psychology (1991), James Wertsch Voices of the Mind: A Sociocultural Approach to Mediated Action (1991) ja Barbara Rogoff Apprenticeship in Thinking: Cognitive Development in Social Context (1990).
4 Kaikki symbolijärjestelmät eivät sovi kaikkien kokemusten mallintamiseen, symbolointiin. Eri symbolijärjestelmät representoivat eri asioita. Esimerkiksi matematiikan numerot onnistuvat hyvin tiettyjen asioiden representoinnissa mutta sopivat huonosti esimerkiksi tunteiden representaatioiksi (vrt. Bion 1970, 91). Koulutuksen tehtävä onkin pyrkiä rakentamaan oppilaan symbolijärjestelmää sellaiseksi, että hän pystyy sitä käyttämällä käsitteellistämään niitä kokemuksia (opettettavia asioita) joita kulloinkin halutaan.

5 Pragmatismista tarkemmin esim. M. White, Science and Sentiment in America: Philosophical Thought from Jonathan Edwards to John Dewey (1972), B. Kuklik, The Rise of American Philosophy: Cambridge, Massachusetts, 18601930 (1977) ja P.P. Wiener, Evolution and the Founders of Pragmatism (1949).

Ks. Schefflerin rationaalisuuskäsityksestä
Holma 2000.

Artikkeli saapui toimitukseen 12.12.2003. Se hyväksyttiin julkaistavaksi toimituskunnan kokouksessa 5.5.2003. 